\title{
PENERAPAN FORMULASI TEPUNG BUAH MANGROVE UNTUK PRODUKSI BISKUIT PADA KELOMPOK "BANK SAMPAH BINTANG MANGROVE" DI GUNUNG ANYAR SURABAYA
}

\section{IMPLEMENTATION OF MANGROVE FRUIT FLOUR FORMULATION FOR BISCUIT PRODUCTION IN BANK SAMPAH BINTANG MANGROVE IN GUNUNG ANYAR SURABAYA}

\author{
Jariyah $^{1 * *}$ and Mohamad Irfan Afandy ${ }^{2)}$ \\ ${ }^{1)}$ Program Studi Teknologi Pangan, Fakultas Teknik, UPN "Veteran” Jawa Timur \\ email: jariyah.tp@upnjatim.ac.id \\ ${ }^{2)}$ Program Studi sistem Informasi, Fakultas Ilmu Komputer, UPN "Veteran” Jawa Timur
}

\begin{abstract}
ABSTRAK
Khalayak sasaran Program Kemitraan Masyarakat (PKM) adalah mitra kelompok pengolah sampah "Bank Sampah Bintang Mangrove" di Gunung Anyar, Surabaya, Jawa Timur. Permasalahan mitra yang dihadapi yaitu minimnya pengetahuan tentang manfaat buah mangrove pada kesehatan, belum diketahuinya tentang formula biskuit fungsional yang disubstitusi dengan tepung buah mangrove, dan pemasaran secara online. Tujuan kegiatan PKM yaitu peningkatan partisipasi kahalayak sasaran dalam pengetahuan manfaat buah mangrove terhadap kesehatan dan pendampingan produksi biscuit dari buah mangrove , serta pengembangan sistem pemasaran melalui pemasaran online. Metode yang dilakukan berupa metode sosialisasi, pelatihan/bimbingan teknis, dan pendampingan. Hasil kegiatan menunjukkan bahwa melalui transfer pengetahuan formulasi biskuit dari tepung buah mangrove dan pendampingan kepada khalayak sasaran mampu menarik kembali minat dan partisipasi untuk lebih peduli pada buah mangrove serta membuka peluang usaha dari kegiatan tersebut. Produk yang dihasilkan dari kegiatan ini berupa produk biskuit buah mangrove sehingga mempunyai nilai tambah dengan harapan apabila usaha ini berhasil maka dapat dikembangkan menjadi produk yang lebih bernilai ekonomi. Produk yang bernilai ekonomi dapat menambah pendapatan bagi khalayak sasaran, sehingga khalayak sasaran dapat mencapai kemandirian ekonomi di area mereka.
\end{abstract}

Kata kunci: Formulasi, Biskuit, Buah mangrove, BSBM, Pemasaran online

\section{ABSTRACT}

The target people of the Community Partnership Program (CPP) is the partner of the "Bank Sampah Bintang Mangrove" (BSBM), which recycle waste group in Gunung Anyar, Surabaya, East Java. The problem come from the limited knowledge about the benefits of mangroves on health, unknown about the functional biscuit formula substituted with mangrove fruit flour yet, and online marketing. The aim of CPP activities is to increase knowledge of participant about benefits of mangroves on health and guidance in production of biscuits from mangroves, and development of marketing systems through online marketing. Method that used are socialization, technical training, and guidance. Result of this activity show that the training of biscuit formulation from mangrove fruit flour and guidance can increase the interest and participate for caring to the mangrove fruit and open business opportunities from it. The created product from this program is mangrove fruit biscuit that have the more value, if this plan was success it can be valuable product. Valuable product can enhance the salary of this society, so they can reach economical side independently in their region.

Keywords: Formulation, Biscuits, Mangrove fruit, BSBM, Online marketing 


\section{PENDAHULUAN}

Kawasan kampung nelayan Gunung Anyar Tambak, Surabaya, lokasinya tak jauh dari muara sungai yang membatasi wilayah Surabaya dengan Kabupaten Sidoarjo, terdapat hutan mangrove yang terjaga kebersihannya, karena ada komunitas pengolah sampah. Kebersihan kawasan ini tak lepas dari keberadaan bank sampah yang digagas oleh Kusniyati dikenal dengan nama "Bank Sampah Bintang Mangrove" atau BSBM, yang berdiri tahun 2012, pada saat itu penggagas konsentrasinya tidak hanya pada sampah tapi juga penyelamatan mangrove [1].

Ada beberapa jenis mangrove yang tumbuh di kawasan Gunung Anyar dan sebagian telah dimanfaatkan oleh kelompok BSBM yaitu bogem (Sonneratia caseolaris), Avicenna, Jeruju dan Nipah). Adapun produk olahan mangrove yang telah dibuat yaitu sirup bogem, jenang bogem, kerupuk dan daun mangrove dibuat urap-urap [2].

Kelompok BSBM ini belum pernah mendapat penyuluhan tentang pentingnya buah mangrove terhadap kesehatan dan produk fungsionalnya, seperti biskuit. Biskuit fungsional merupakan produk biskuit yang tidak hanya bersifat mengenyangkan namun juga memiliki nilai kesehatan. Hasil penelitian menunjukkan bahwa formulasi biskuit dengan substitusi 20\% tepung buah mangrove memiliki sifat antidiabet dan antikolesterol [3], [4], [5].

Berdasarkan hasil survei lokasi terutama untuk produksi kue kering perlu dikembangkan, terutama biskuit. Selama ini kelompok BSBM hanya memproduksi sirup dengan bahan baku buah mangrove jenis bogem (Sonneratia caeolaris) dan belum pernah diproduksi menjadi biskuit. Oleh karena itu perlu dikembangkan produk biskuit fungsional dengan mensubsitusi tepung buah mangrove dengan tepung mocaf.

Adanya Program Kemitraan Masyarakat (PKM) ini diharapkan kelompok BSBM dapat memproduksi biskuit yang diformulasikan dengan tepung buah mangrove. Sehingga produk biskuit yang dihasilkan memiliki sifat fungsional dan mengoptimalkan sumber daya lokal yang ada. Hal ini sangat penting mengingat buah mangrove baik untuk kesehatan. Beberapa hasil penelitian melaporkan bahwa buah mangrove jenis mangrove (Sonneratia caseolaris) memiliki kandungan antioksidan cukup tinggi [6], kandungan serat pangan buah mangrove bersifat mengenyangkan, menurunkan kadar gula darah, dan kolesterol [7], [8], kaya provitamin A, vitamin B5, vitamin $\mathrm{B} 2$, vitamin $\mathrm{C}$ [9], [10], sehingga sangat baik untuk kesehatan.

Kegiatan PKM meliputi sosialisasi manfaat buah mangrove terhadap kesehatan, melatih kelompok BSBM membuat biskuit dengan formulasi yang tepat, sehingga dihasilkan biskuit fungsional dengan kemasan yang menarik, dan dapat dipasarkan secara online sehingga dikenal masyarakat dan marketable. 


\section{METODE}

Lokasi kegiatan PKM adalah balai pertemuan BSBM di desa Gunung Anyar Tambak Surabaya. Khalayak sasaran kegiatan yaitu masyarakat yang tergabung dalam kelompok BSBM, sebanyak 19 orang beserta ketua BSBM. Berdasarkan permasalahan yang telah uraikan sebelumnya dan kesepakatan antara tim pengusul dan mitra maka solusi yang ditawarkan untuk mengatasi permasalahan yang ada dapat dilakukan dengan metode pemberian sosialisasi pengetahuan tentang manfaat buah mangrove terhadap kesehatan, memberikan pelatihan pembuatan biskuit dengan formulasi yang menggunakan bahan baku tepung buah mangrove jenis pedada (Sonneratia caseolaris), serta memberikan pelatihan pemasaran produk secara online.

\section{HASIL DAN PEMBAHASAN}

Pengabdian masyarakat melalui program PKM ini telah dilaksanakan pada bulan Juni sampai September 2019, di awali dengan koordinasi dengan anggota dan mitra untuk pelaksanaan kegiatan PKM. Kemudian pengurusan ijin dan persiapan bahan serta peralatan lainnya. Pada tahap awal dilakukan pengambilan buah mangrove jenis pedada di lokasi petani mangrove setempat seperti terlihat pada Gambar 1.

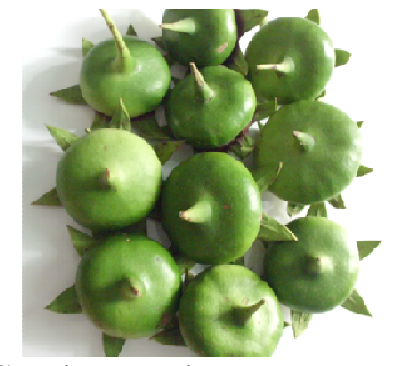

Gambar 1. Gambar Buah Mangrove Pedada Selanjutnya buah tersebut diproses menjadi tepung, dengan tahapan pengupasan dan pencucian, blancing suhu $80^{\circ} \mathrm{C}$ selama 5 menit, pelumatan buah, penyaringan, pengeringan dengan kabinet suhu $\pm 50-60^{\circ} \mathrm{C}$ selama 15-18jam, penggilingan dan pengayakan. Selain tepung buah pedada juga membuat tepung mocaf sebagai bahan campurannya, proses pembuatan tepung mocaf mengacu pada penelitian Hakim (2016) dengan tahapan pengupasan, pencucian, pengecilan ukuran, fermentasi dengan penambahan starter Lactobacillus plantarum dengan perbandingan 1:1 selama 72 jam, pencucian dan penirisan, pengeringan kabinet $60^{\circ} \mathrm{C}$ selama 8 jam, penggilingan dengan blender dan pengayakan 80 mesh. Proses penepungan dilakukan dilaboratorium Teknologi Pengolahan Pangan Universitas Pembangunan Nasional "Veteran" Jawa Timur.

Proses selanjutnya yaitu pembuatan biskuit dengan menggunakan bahan tepung buah mangrove jenis pedada dengan tepung mocaf yang formulasinya disampaikan pada saat pelatihan. Pada kegiatan tersebut para peserta terlihat aktif mengikuti kegiatan baik 
pada saat penyampain materi, diskusi dan pembuatan produk. Dengan diadakannya kegiatan PKM diharapkan dapat meningkatkan pengetahuan dan ekonomi peserta pelatihan dengan menerapkan materi pelatihan dengan pendampingan yang baik dan konsisten.

Partisipasi anggota BSBM dan warga sekitar dengan diadakannya kegiatan ini sangat positif dan antusias ditunjukan dari banyaknya peserta yang mengajukan pertanyaan saat sesi diskusi. Berdasarkan kuesioner dari perseta pelatihan mengenai manfaat buah mangrove untuk kesehatan mampu diterima oleh anggota kelompok BSBM dengan baik. Hal ini dapat dilihat dari hasil kuisioner bahwa seluruh atau 100\% dari peserta pelatihan telah memahami manfaat dari buah mangrove terhadap kesehatan, karena mereka telah memanfaatkan buah mangrove untuk produk sirup bogem yang dapat digunakan sebagai obat .

Untuk lebih memahami materi yang telah disampaikan oleh pengusul, maka peserta diajak langsung untuk praktek pembuatan biskuit dari tepung buah mangrove, yang menggunakan formulasi $80 \%$ tepung mocaf dan $20 \%$ tepung buah mangrove. Kualitas produk biskuit yang dihasilkan dari kegiatan ini dapat langsung dirasakan oleh masyarakat serta adanya keinginan untuk melakukan pengolahan sendiri maupun berkelompok.

Berdasarkan hasil kuesioner terhadap pembuatan biskuit dengan tepung buah mangrove menunjukkan bahwa 100\% peserta pelatihan memahami pembuatan biskuit secara umum hanya saja bahan yang digunakan adalah tepung buah mangrove, dan mereka sangat aktif dalam mengikuti pelatihan dalam kegiatan PKM ini. Hal ini menunjukkan bahwa mitra pelatihan sangat paham tentang cara pembuatan biskuit secara umum maupun pembuatan biskuit mangrove secara spesifik.

Peserta BSBM juga diberi pengetahuan tentang teknik pengemasan produk biskuit. Dalam hal ini pengemas yang digunakan jenisnya standing pouch plastik dengan berat 50 gram perkemasan produk, seperti yang terlihat pada Gambar 2.

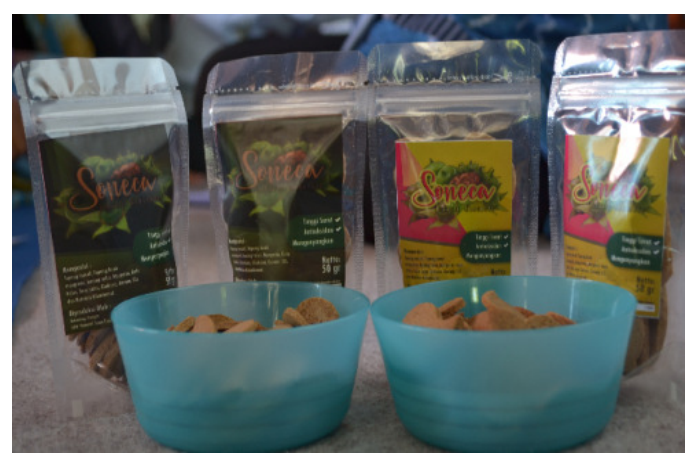

Gambar 2. Hasil praktek pelatihan pembuatan biskuit

Berdasarkan kuesioner menunjukkan bahwa teknik pengemasan produk diperoleh hasil $89 \%$ anggota mitra telah memahami bagaimana cara melakukan pengemasan khususnya produk biskuit dengan baik. Khalayak sasaran juga diberikan pelatihan secara online melalui tokopedia, Media Pemasaran melalui Instagram, Whatsapp, facebook, instragram. 


\section{KESIMPULAN}

Program kemitraan Masyarakat dalam Penerapan Formulasi Tepung Buah Mangrove untuk Produk Biskuit Pada Kelompok "Bank Sampah Bintang Mangrove" yang dilaksankan mampu meningkatkan pengetahuan dan keterampilan mitra. Keterampilan yang didapatkan oleh peserta diharapkan mampu diterapkan dengan baik dalam kehidupan sehari hari maupun dalam berwirausaha, untuk dipasarkan secara online melalui tokopedia, facebook, whatsapp dan instragram.

\section{UCAPAN TERIMAKASIH}

Penulis mengucapkan terimakasih kepada Kemenristek Dikti yang telah memberi dana pengabdian masyarakat pada skim PKM, tahun 2019.

\section{DAFTAR PUSTAKA}

[1] Ardianto, A.. 2018. Bank Sampah Bintang Mangrove, Motor Penggerak Perekonomian Warga.html, diakses tanggal 10 Oktober 2018

[2] Kusniyati. 2018. Hasil Wawancara dengan kelompok "Bank Sampah Bintang Mangrove" desa Gunung Anyar Tambak, kelurahan Gunung Anyar, Surabaya

[3] Jariyah, Widjanarko, S.B. , Estiasih, T. and Yunianta. 2016a. Quality evaluation of Wheat-Pedada Fruit Flour (PFF) biscuit with different emulsifiers. Agriculture and Agricultural Science Procedia 9 ( 2016 ) 518 - 524.

[4] Jariyah, Yektiningsih, E and Sarofa, U. 2016b. Sensory evaluation of biscuit produced from wheat and mangrove fruit flour (MFF) mixtures. Proceeding The 2nd International Conference on Food, Agriculture, and Natural Resources 2016. ISBN 978-602-203-995-2.

[5] Jariyah, Yektiningsih, E and Sarofa, U. 2018. Effect of Partial Replecement of
Wheat Flour with Various Mangrove Fruit Flours and Different Emulsifiers on Physicochemical Properties Biscuit. Indonesian Journal of Agricultural Research. Vol.1 No.2: 152-161.

[6] Ahmed, R., S.J. Moushumi, H. Ahmed, M. Ali, W. M. Haq, R.Jahan, and M. Rahmatullah. 2010. Serum Glucose and Lipid Profiles in Rats Following Administration of Sonneratia Caseolaris (L.) Engl. (Sonneratiaceae) Leaf Powder in Diet. Advances in Natural and Applied Sciences, 4(2):171-173.

[7] Jariyah, Azkiyah, L., Widjanarko, S.B., Estiasih, T., Yuwono, S.S and Yunianta. 2013. Hypocholesterolemic Effect of Mangrove (Sonneratia caseolaris) Fruit Flour in Wistar Rats. International Journal of Pharm Tech Research. vol.5, No.4, pp.1619-1627.

[8] Jariyah, Widjanarko, S.B. , Estiasih, T. and Yunianta. 2014. Hypoglycemic effect of Mangrove (Sonneratia caseolaris) Fruit Flour $(P F F)$. in alloxan-induced diabetic rats. International Journal of PharmTech Research. Vol.7, No.1, pp 31-40.

[9] Manulu, R.D.E. 2011. Kadar beberapa vitamin pada buah Mangrove (Sonneratia caseolaris) dan hasil olahannya Skripsi. Dep.Tekn.Hasil Perairan . FPIK-IPB.

[10] Rahmatullah, M. , Md. N. K. Azam, S. Pramanik, Sania, S.Rahman, and R. Jahan. 2012. Antihyperglycemic activity Evaluation of Rhizomes of Curcuma zedoaria (Christm.) Roscoe and Fruits of Sonneratia caseolaris (L.)Engl. International Journal of PharmTech Research. 4(1):125-129. 